\title{
Diffuse Interest Groups and Regulatory Policy Change: Financial Consumer Protection in Turkey
}

\author{
Pre-print version
}

Published in Interest Groups \& Advocacy 9(2): 220-243

DOI: $10.1057 / \mathrm{s} 41309-020-00086-\mathrm{W}$

\begin{abstract}
This article examines why and how a regulation on retail banking fees, commissions, and charges emerged in Turkey after a long period of regulatory forbearance. The article shows that when regulatory forbearance caused stasis, and the 'statist', exclusionary policymaking context limited consumer groups' access to the policymaking process, consumer groups challenged the policy regime of the banking sector and the regulator by appealing to another state actor, the Ministry of Customs and Trade. The Ministry took advantage of an opportunity structure to pass a new consumer protection law which assigned a de facto mandate on the regulatory agency to regulate fees, commissions, and charges. The article argues that the regulatory policy change was a product of a policy regime change with the Ministry emerging as a veto player, as it redefined the institutional arrangements in the policymaking process, and imposed its preferences and its stricter policy approach. As such, the article contributes to our understanding of the conditions of how diffuse interest groups can trigger regulatory policy change, but more importantly policy regime change.
\end{abstract}

Keywords: Diffuse interest groups, policy regimes, regulatory policy change, policy regime change, financial consumer protection, banking regulation

\section{Introduction}

Why and how does a regulatory policy change emerge after a long period of stasis? If diffuse interest groups have a role in the process, how could they achieve or trigger regulatory policy change which may also reflect policy regime change? And, what are the conditions of such success (or failure)? Research suggests that diffuse interest groups are considered to have limited capacity in the policymaking process, in particular technical policy areas due mainly to the collective action problem given their disjointed nature of mobilisation (Delacote 2009; Dür and Mateo 2013; Olson 1965; Pagliari and Young 2016), or the dominance of 'quiet politics' between the state and the structurally powerful private sector (Culpepper 2010; 2015; Lindblom 1977). Yet they can still lobby at the international and/or the domestic levels to influence the policymaking process (Anheier 2014; Kastner 2014; 2017; 2019; Trumbull 2012; Ziegler and Woolley 2016). They may try to influence public opinion and mobilise 
citizens (Dür 2019; Dür and De Bièvre 2007; Dür and Mateo 2014). If mobilisation has limited influence or diffuse interest groups face organisational and/or contextual challenges, they may also attempt to expand the conflict zone by appealing to strategic, resourceful allies that can mediate societal demands (Baumgartner and Jones 1991; 1993; Downs 1972; Kastner 2017; 2019; Kollman 1998; Schattschneider 1975[1960]).

While we know how diffuse interest groups might influence the policymaking process, not much is known about how diffuse interest groups could lead or trigger policy regime change. This is closely related to calls for studies that link the literatures on (diffuse) interest groups and public policymaking (see Hojnacki et al 2012). Filling that void, the article shows how diffuse interest groups could trigger either individually or with assistance of allies not only policy change but more significantly policy regime change. The article also contributes to the public policy field as the policy regime literature has yet to examine how diffuse interest groups' insider and outsider tactics could constitute the initial stressors for policy regime change, which is the very product of the agency of diffuse interest groups and their allies in redefining and reframing problems and solutions (May and Jochim 2013, 446; see also Wilson 2000).

The case of a regulation on retail banking fees, commissions, and charges in Turkey is illustrative in that sense. Bakir and Öniş $(2010,99)$ note that the Banking Regulation and Supervision Agency (hereafter "BRSA") failed to monitor overpricing of products and oversee consumer protection. Thus, the BRSA's regulation in 2014 leads us to wonder why and how a regulation was introduced now but not before. This is a significant step the BRSA has taken to regulate fees, commissions, and charges because banks were free to charge any service, product at a level they wished. Besides such contextual specificities, the case has two 
broader implications. Firstly, financial consumer protection rose to the top of the agenda around the world after the Global Financial Crisis, in particular developed countries. While the literature mainly studies the political economy of financial consumer protection in the United Kingdom, the United States, and the European Union (EU) (Akinbami 2011; Kastner 2017; 2019), less is known about developing country contexts. For example, the rise of financial consumer protection in the policy agenda does not have a crisis origin in Turkey. Thus, the article fills the gap in the broader literature on the political economy of financial consumer protection in developing countries. While doing so, it shows the impact of consumer group activism in developing countries in the regulatory policymaking process (Hilton 2009; Hochstetler 2012). Secondly, the article reports a positive case of consumer group mobilisation triggering change in regulatory policy and policy regime in a context where the "statist" policymaking style limits the influence of societal demands and their participation in the policymaking process (Bolukbasi and Ertugal 2018). ${ }^{1}$ The case of financial consumer protection is puzzling because "the source of power [in Turkey] is the state, not society, resulting in a state-centric policy with an aversion to, or even dislike of, autonomous societal actors... [whose] ...impact remains limited [in the policymaking process]" (Bolukbasi and Ertugal 2018, 357, 363). The findings reveal that consumer groups were able to trigger regulatory policy change by appealing to another state actor, which then led to a change in policy regime.

The article shows that despite organisational challenges and exclusionary policymaking context sustained by the policy regime of the BRSA and the banking sector, consumer groups achieved to trigger change in regulatory policy change, as well as policy regime change by appealing to a resourceful ally, the Minister of Customs and Trade (currently Ministry of Trade, hereafter "Ministry"). Getting the Ministry as an ally against the policy regime of the 
BRSA and the Turkish banking sector was essential because the institutionalised exclusionary policymaking context did not allow insider tactics through direct contact with regime actors and participation in the policymaking process. Driven by consumer group lobbying and consumer complaints to the Ministry, the Ministry capitalised on an opportunity structure when it updated the Consumer Protection Law (hereafter "Law") in 2013, while making the Law compliant with Chapter 28 of the Acquis Communautaire of the EU. The $28^{\text {th }}$ Chapter of the acquis steers consumer and health protection. Therefore, it does not particularly address consumer protection in banking fees, commissions, and charges. However, the Ministry capitalised on that opportunity structure to mediate societal demands with incorporation of a regulation on retail banking fees, commission, and charges in the new version of the Law enacted in $2013 .^{2}$ As such, the Ministry was able to expand turf (Allison 1971; Wilson 1990) by imposing a de facto mandate on the BRSA in regulation of retail banking fees, commissions, and charges in liaison with the Ministry. ${ }^{3}$ This reminds us that the state is not a monolithic actor. ${ }^{4}$ Fragmentation within the state can create opportunities for various interest groups to take part in the policymaking process in an impactful manner. Admittedly, the state is an intermediary between various interest groups. While fulfilling that role, different branches of the state apparatus may serve distinct constituencies.

Perhaps most significantly, regulatory policy change reflects a change in the policy regime previously maintained by the BRSA and the banking sector. Policy regime change is observable with consumer group activism triggering the emergence of the Ministry as an influential veto player which has a stricter regulatory approach to financial consumer protection compared to that of the BRSA. Moreover, the Ministry stepped into the BRSA's mandated policy area, namely banking regulation, by imposing a de facto mandate on the BRSA for regulation of fees, commissions, as the BRSA regulated fees, commissions, and 
charges in $2014 .{ }^{5}$ Consequently, the policymaking process can hardly ignore the Minsitry's capabilities and power, as its presence and active participation in the policymaking process have become indispensable in financial consumer protection. Reflecting the policy regime change, the Ministry began to utilise its sanctioning power. For example, the Ministry's onsite supervision monitoring compliance of the banking sector with the Law is illustrative of policy regime change, as the Ministry sanctioned four banks in 2015 for non-compliance (BloombergHT, November 24, 2015).

This article adopted an exploratory case study method. The empirics relied on field research conducted in the first quarter of 2016 in Istanbul and Ankara. Field research included 22 indepth, semi-structured elite interviews. Interviews were conducted with senior regulators, a senior official in the Ministry, senior-level bankers in privately-owned banks, foreign-owned banks, state-owned banks, and senior officials in the Banks' Association of Turkey, and four senior-level representatives of consumer groups of the four largest consumer groups by member size. Written sources, such as the Consumer Council communiqué, minutes of the Committee discussion on the draft of the Law in the National Assembly, the BRSA's annual reports, and media reports, complemented the interviews. Transcribed interviews and written sources were analysed on NVivo. Coding and data analysis continued until the analysis reached the theoretical and conceptual "saturation point".

The rest of the article proceeds as follows. The next section revisits policy regimes and the role of diffuse interest groups in triggering policy change and policy regime change. This is followed by an overview of financial consumer protection in Turkey and the background leading to the regulation on retail banking fees, commissions, and charges. The article then 
presents the process leading to the regulation. It ends with a discussion and suggestions for future research.

\section{Literature Review}

\section{Policy Regimes and Regulatory Forbearance}

A policy regime is the constellation of ideas, institutional arrangements, actors, and policies (Jochim and May 2010; May and Jochim 2013; Wilson 2000). Actors are insiders with substantial influence and control over the policy issue. Insiders may include the private sector actors, the public sector actors, public interest groups, or even international organisations. Institutional arrangements define the rules and channels of interactions and resource exchange between regime insiders (May and Jochim 2013; Wilson 2000). Institutional arrangements also define which actors are insiders and outsiders. Such capacity of institutional arrangements enables a policy regime to limit outsiders' access to the policymaking context by denying penetration of alternative policy images, as the policy regime designs and implements policies in line with the regime's policy paradigm (Baumgartner and Jones 1991; 1993; Jochim and May 2010; May and Jochim 2013).

Policy ideas constitute the 'glue' of the policy regime. They provide the basis that keeps the regime actors bounded together given their shared policy approach (Blyth 1997; 2002). More importantly, policy ideas constitute a shared perspective, which in turn define the regime's cause-effect relationships, seriousness of the issue, appropriate response, and images of the policy targets about "who wins and loses" (Wilson 2000, 257). Here, policy ideas matter particularly when regulators' ideational orientation overlaps with the interests of the regulatee, increasing the likelihood of 'regulatory capture' (Kwak 2014). Regulatory capture might stem from regulatee's lobbying, revolving doors or other (in)direct exchange of 
benefits between the regulatee and the regulators (Becker 1983; Peltzman 1976; Laffont and Tirole 1990; Stigler 1971). Perhaps more importantly, the policy ideas can be instrumental for diversion of policies towards the regulatees' preferences through the regulator's "light-touch", non-interventionist regulatory approach which might originate from regime actors' belief in self-regulatory markets. In that case, the policy paradigm is likely to cause regulatory forbearance, which is "a reduction in the stringency with which regulations are enforced" (Gordon and Hafer 2014, 209). ${ }^{6}$

In sum, policy regimes produce policies that embody normative values, causal beliefs, and attention of regime actors on the policy area. Moreover, policies reflect " $[t]$ he rules and routines of the implementing agency. These goals [of the policy regime], rules and routines legitimize the policy" (Wilson 2000, 258). A significant consequence of such routines, rules, and goals that are pursued for a long period of time is policies to gain long-lasting legacies and to create path dependency (Pierson 2000). With this, regime actors can achieve policy durability for a decade or more, which also reflects regime actors' commitment to core objectives, means, and principles (May and Jochim 2013, 433).

\section{Policy Regime Change and Diffuse Interest Groups}

While a policy regime asserts its monopoly for a long period of time, such monopoly is not unshakable. Here, Wilson's (2000) a five staged policy regime change is a useful framework. For Wilson (2000, 259-267), policy regime change occurs in five stages. Firstly, stressors/enablers act as catalysts for change by demonstrating anomalies, increasing visibility of policy problems, and putting pressure on the institutional arrangements. Stressors/enablers include natural and man-made disasters, demographic changes, scandals, spillover from other issue areas. 
Secondly, the existing paradigm observes a dramatic shift (Wilson 2000, 262-263). Stressors/enablers constitute the opportunity structure either for regime actor to recognise the need for a change endogenously. Or, regime outsiders can rely on the opportunity structure to challenge the regime's ideational approach. Thirdly, stressors/enablers interact with forces for a shift in policy ideas, and they together induce a legitimacy crisis for the policy regime, its policy approach, institutional arrangements, and whereby policies (Ibid, 264). In the fourth stage, power shifts occur in the form of emergence of new actors, policy venues, or new sources of power, which are the product of the loss of legitimacy of the existing regime, the mobilisation of regime outsiders among other factors (Ibid, 264-265). Finally, the emergence of new actors, coalitions, which publicise an alternative policy approach, poses serious risks to monopoly of the policy regime over the policy issue. As such, rising pressure calls for change in the institutional arrangements.. If the outsiders succeed in posing sufficient stress on policy regime durability, we can expect change in policies, shifts in policy approaches, and changes in institutional arrangements, and ultimately policy regime change (Ibid, 265).

Here, diffuse interest groups, in our case consumer groups, as outsiders, can have a(n) (in)direct influential role in challenging a policy regime. ${ }^{7}$ As a 'transmission belt' between ordinary citizens and policymakers (Albareda 2018), they play a significant role in triggering the initial stressors that disturb policy regime stability by mobilising constituencies, forming alliance with actors that hold and publicise alternative policy approaches, provide access to and influence in the policymaking process. Consequently, these might lead to legitimacy crisis, power shift, and finally policy change and policy regime change. Indeed, diffuse interest groups are considered to lack significant political power compared to that of the business due particularly to collective action problem (Olson, 1965) and/or high costs of gathering information. Despite such constraints, the strength of diffuse interest groups 
originates from their capacity to raise "voice" (Hirschman 1970). But, how could they do so? For this, mobilisation is a necessary factor (Meyer 2004). To get mobilised, diffuse interest groups need to acquire a set of resources such as supply of information, capabilities to mobilise the constituency, and financial and human resources (Dür 2008; Dür and Mateo, 2014; Flöthe 2019; Maloney et al 1994).

Effective tactics are imperative for success. The literature points to two main tactics employed for access and influence the policymaking process: insider and outsider. ${ }^{8}$ Insider tactics aim to influence the policymakers through direct interaction. These tactics include contacting ministers, public servants, political parties, parliamentary committees through in-person meetings, phone calls, e-mail exchanges (Binderkrantz 2005, 696; De Bruycker and Beyers 2019, 59). Outsider tactics relate to expansion of the conflict zone by manipulation of policy images in the broader audience with the aim of creating societal, political pressure on policymakers to act upon a policy problem (Baumgartner et al 2009; Baumgartner and Jones 1991; 1993; Downs 1972; Kollman 1998; Schattschneider 1975[1960]). These tactics include publishing reports, demonstrations, organising petitions, public campaigns to mobilise the constituency, meetings with (authoritative) actors that could assist diffuse group's efforts towards policy change (Binderkrantz 2005, 696; De Bruycker and Beyers 2019, 59). While a single tactic could be employed, groups can also rely on a mix of insider and outsider tactics (see Mahoney 2007).

The employment of a tactic or a mix is conditional on the policymaking context, as the context structures channels of mobilisation and whether or not diffuse interest groups can gain access to and have considerable influence in the policymaking process (Baumgartner 1996; Beyers 2004; Binderkrantz 2008, Binderkrantz and Pedersen 2019; Dür 2008; Dür and Mateo 
2013; Kriesi et al 2007; Meyer 2004; Meyer and Minkoff 2004; McAdam et al. 1996; 2001; Weiler and Brandli 2015). For example, institutional arrangements assign certain roles and mandates to certain actors to whom (diffuse) interest groups can appeal (Dür 2008). Moreover, the policymaking context can have an exclusionary nature, which narrows not only available insider tactics but also variety of outsider tactics. For example, a repressive political regime could limit diffuse interest group mobilisation (Rhee and Lee 1996). Or, regardless of the political regime, the policymaking process could be dominated by a limited number of actors such as the private sector (Culpepper 2010; 2015; Weiler et al 2019), restricting diffuse interest group access to and/or reducing their influence in the policymaking process.

Besides the context, diffuse interest groups are shown to mainly opt for outsider tactics given their limited access for direct contact with regime actors and whereby limited influence in the policymaking process, which could originate from either the choice of the group or lack of recognition by policymakers (Binderkrantz 2005; 2008; Binderkrantz and Krøyer 2012; De Bruycker 2019). Under these conditions, diffuse interest groups can appeal to media and/or mobilisation of the constituency. Diffuse interest groups are expected to benefit from appealing to media to influence public opinion, increase issue salience, and mobilise constituencies (Binderkrantz et al 2015; Dür and Mateo 2014). However, skills, resources (Binderkrantz 2005; Thrall 2006) as well as media attention are necessary for such success. In case of limited impact of these tactics and/or employment of a complementary tactic, diffuse interest groups can expand the conflict zone by appealing to strategic, resourceful allies vis-àvis the policy regime (Kastner 2017; Mahoney and Baumgartner 2015). The role of allies becomes critical insofar as their strategic and political position allows them to make authoritative decisions that can challenge the policy regime. As such, recruiting allies can multiply the impact of strategies and resources of diffuse interest groups because allies can 
open doors for access to and influence in the policymaking process, and supply a multitude of critical resources (e.g., information, human, financial) diffuse interest groups may lack.

Figure 1: The process of policy regime change and policy change in financial consumer protection

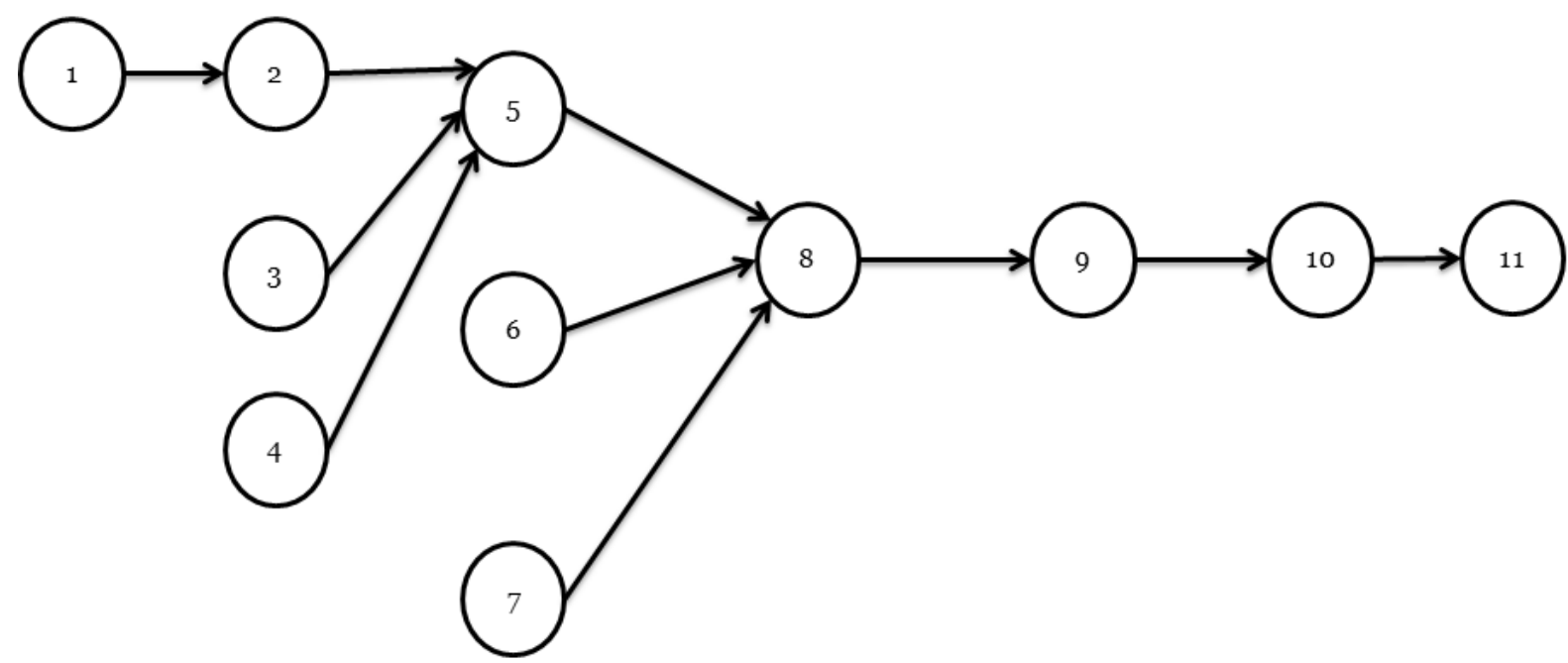

Note: 1) Issue salience rises among consumers; 2) Consumer groups place complaints to the BRSA, organise demonstrations; 3) Low media attention to consumer group demands; 4) Low organisational capacity of consumer groups to lead or trigger policy change on their own; 5) Policy regime is irresponsive, policy remains the same: causing legitimacy crisis; 6) Consumer groups target the Ministry (e.g., Consumer Council, Consumer arbitration panels); 7) Face-to-face meetings with the Minister; 8) The Minister and the Ministry emerge as a key ally: publicising an alternative policy paradigm, 9) Compliance with the EU acquis; 10) As a consequence of policy regime change with power shift, paradigm shift, and change in institutional arrangements, the Consumer Protection Law of 2013 is enacted; 11) The BRSA introduces the regulation on fees, commissions, and charges in 2014.

In sum, in light of the above discussion, Figure 1 depicts Wilson's (2000) slightly refined linear policy regime change framework and change in financial consumer protection policy in Turkey. The rest of the article discusses the process leading to policy regime change and policy change in financial consumer protection in Turkey.

\section{Financial Consumer Protection in Turkey}

The notion of consumer protection was first adopted in the Turkish legal system with the enactment of the first version of Law in 1995 (Gezder 2006). ${ }^{9}$ The 1995 Law was amended in $2003 .{ }^{10}$ The previous and the updated version allowed consumers to sue malpractice in specialised consumer courts without placing legal complaints to regular courts. 
As for financial consumer protection, the previous versions of the Law included measures on consumer loans, but it did not have specific measures on retail banking fees, commissions, and charges. The revised 2013 version included such regulations. ${ }^{11}$ For example, Article 4 of the Law adjudicates that (a) banks cannot charge compound interest rate; (b) banks must inform consumers about the rules and conditions of a retail banking service beforehand; and (c) banks cannot change rules and conditions without seeking the consumer's consent. Most significantly, Article 4 assigns a role to the BRSA to regulate fees, commissions, and charges, which was introduced in 2014. The interviewed regulators and the official in the Ministry mentioned that there were at least 60 items charged by the banking sector. The banks were free to charge any service or product they wanted to. The BRSA's regulation reduced that number to 20 with simplification, clarification, and removal of several items from the list. Consequently, the regulation allowed to charge fees, commissions, or charges on deposit withdrawal, money transfers, annual credit card fee, payments to third persons among others, while, it allowed consumers cool-off periods for retail banking services. ${ }^{12}$ Additionally, it imposed a cap on early loan payments, which caused the rise in issue salience among consumer groups.

Here, it is useful to understand the politico-economic background leading to the regulation in 2014. The local economic crisis in 2000-01 had led to a new environment for the banking sector. The International Monetary Fund (IMF) had highlighted that the Turkish banking sector would have observed a decline in its profitability due to a decline in chronic public budget deficit (Aricanli and Rodrik 1990). The banking sector was the main financer of public budget deficit through its purchase of Treasury bills which accrued high interest-rate income (IMF 2000). Within the post-local crisis context, the banking sector observed a decline in interest-rate income. As a response, the Turkish banking sector "noticed [the potential of] 
consumer banking ... thereby [retail banking] fees and commissions as an additional source of [non-interest] income."13

A former Chairman of the BRSA stated in 2011 that the decline in interest rates since the early 2000 s led to a "race in the sector to generate revenue from non-interest [income] sources". ${ }^{14}$ The race to raise revenues caused previously uncharged retail banking services becoming chargeable, as high interest rates in the past decades did not force banks to charge retail banking services since profitability relied on lending to the state (BRSA 2014). As clearly put by a senior banker

$[T]$ he sector was able to cover operational costs... since the interest rate included an implicit fee for the banking services. Then the return on deposits declined while costs kept rising. As a result, the business became [financially] less sustainable [without charging fees, commissions]. ${ }^{15}$

The banking sector's increasing reliance on non-interest income is clearly shown in Figure 2. The share of non-interest revenue generated from commissions, fees, and charges in total income (i.e. the sum of non-interest and interest income) has steadily risen from 6.5 percent in 2002 to 15.6 percent in 2013 before the regulation on retail banking services fees, commissions and charges was put into force in 2014. The share of revenue generated from fees, commissions and charges also reflects the dominance of that revenue source among other sources of non-interest income. The share of fees, commissions and charges in total non-interest income has risen from 43 percent to 68 percent between 2002 and 2014. 
Figure 2: Non-interest income and fees, commissions and charges, 2002-2014

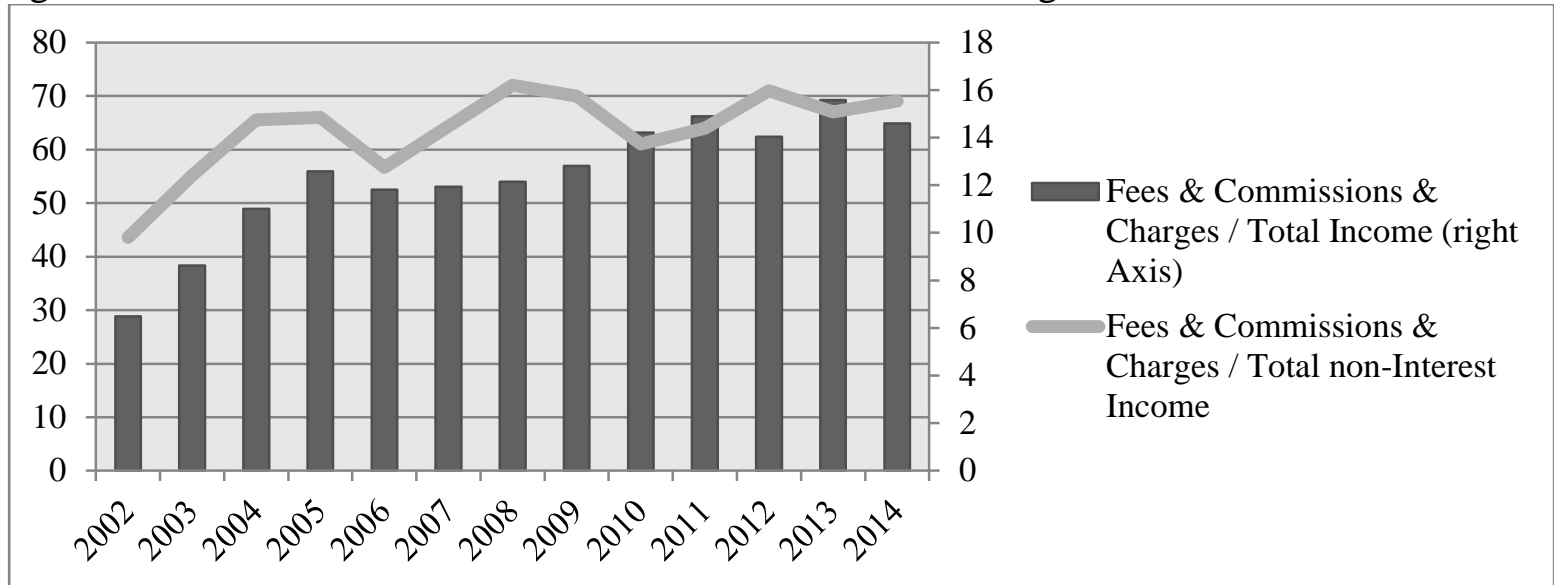

Source: Banking Regulation and Supervision Agency, author's compilation.

While the banking sector has become more reliant on retail banking fees, commissions, and charges, Table 1 indicates that interest rates, charges and fees rank among the top concerns of financial consumers besides other issue areas such as complaints about consumer loans, negative credits and credit cards. In recent years, it has become apparent that consumers' complaints about fees, commissions and charges to the BRSA have risen as the appeals have reached one of the highest levels of 18.6 percent and 21 percent in 2013 and 2014, respectively.

Table 1: Consumer complaints, 2004-2014, in percentages

\begin{tabular}{|l|c|c|c|c|c|c|c|c|c|c|c|}
\hline \multicolumn{1}{|c|}{ Subject/ Year } & 2004 & 2005 & 2006 & 2007 & 2008 & 2009 & 2010 & 2011 & 2012 & 2013 & 2014 \\
\hline Credit cards & 22.5 & 23.6 & 27 & 31.8 & 33.5 & 27.2 & 27.7 & 23.2 & 13 & 10.9 & 13.9 \\
\hline $\begin{array}{l}\text { Deposit/Participation } \\
\text { fund accounts }\end{array}$ & 9.5 & 11.5 & 8.6 & 9.6 & 11.3 & 7.3 & 11.4 & 9.8 & 13.7 & 8 & 12.8 \\
\hline $\begin{array}{l}\text { Interest rates, Charges, } \\
\text { and Fees }\end{array}$ & 5.9 & 8.9 & 6.6 & 7.9 & 4.2 & 8.6 & 8.9 & 8.2 & 15.7 & 18.9 & 21 \\
\hline Consumer loans & 5.7 & 8.1 & 12.7 & 14.5 & 18.8 & 23 & 18.1 & 24.9 & 19.4 & 16 & 10.7 \\
\hline Negative credits & 6.2 & 3.5 & 5.1 & 3 & 3.7 & 7.9 & 6.6 & 6.4 & 5 & 7.2 & 3.8 \\
\hline Non-cash/corporate loans & 3.4 & 1.2 & 0.1 & 1.3 & 5.4 & 8.6 & 4.3 & 3.1 & 3.1 & 4.8 & 2.7 \\
\hline Others & 46.9 & 43.2 & 39.9 & 31.9 & 23.1 & 17.4 & 23 & 24.4 & 30.1 & 34.2 & 35.1 \\
\hline Total number of cases & 1023 & 1387 & 1765 & 1838 & 2803 & 6329 & 7627 & 9904 & 13626 & 16870 & 27316 \\
\hline
\end{tabular}

Source: Banking Regulation and Supervision Agency Annual Reports 2004-2015, author's compilation.

In short, while consumers have been complaining about fees, commissions, charges, and the Turkish banking sector has been generating more non-interest income, the BRSA did not address a persistent policy problem for a decade. However, it introduced a regulation in 2014 
as a follow up to the new version of the Law enacted in 2013. Next, we show how and why the BRSA did so.

From Regulatory Forbearance to the Regulation of Retail Banking Fees, Commissions, and Charges

Regulatory Forbearance and the Policy Regime of the Turkish Banking Sector and the BRSA

A feedback mechanism, similar to practices in many other countries and international organisations, regulates the policymaking process in banking regulation in Turkey. The BRSA to publicises draft regulations on its website. Following the publication of draft regulations, anyone can submit a feedback to the BRSA. However, the policymaking process is dominated by the banking sector and the BRSA, and is exclusionary as it mainly takes place through the feedback system. The feedback system sets the institutional arrangements of the policy regime regulating the rules of interaction between the two actors. The feedback system begins when 'the BRSA asks for feedback from the sector. The [Banks'] Association [of Turkey] forwards the BRSA's request to individual banks. The banks reply to the Association's request. Finally, the Association consolidates the feedback and sends it back to the BRSA."16

While the two actors work closely through the feedback mechanism, diffuse interest groups might not participate actively in the policymaking process compared to concentrated interest groups (see Pagliari and Young 2016). Even if they try to do so, their involvement might be restricted, or involvement does not guarantee effective participation. This is closely related to the "statist" policy style that does not allow representation of societal demands in the policymaking process (Bolukbasi and Ertugal 2018). A consumer group representative mentions that "the BRSA never consults us because it is not speaking with us. That is why we 
tried to influence the Ministry to make our voice heard."17 Another consumer group representative emphasises the role and power of the Banks' Association of Turkey: "The Banks' Association is very influential. It is one of the members of the structure."18 The exclusionary policymaking process implies that "[a]ccess is something that not all groups have, and it must in some real sense be won or granted" (Halpin and Fraussen 2017, 726).

The policy regime also had an ideational basis. Here, the mandate of the BRSA ${ }^{19}$ plays a critical role as organisational mandates define organisational roles and boundaries of legitimate act. As put by a former senior regulator

The mandate of the BRSA did not include consumer protection [except deposit protection]... [Yet] [I]f we had observed a trend [in complaints] concentrating in a bank, we assigned supervisors to identify potential causes... [Thus,] we did not need a formal, sector-level abiding regulation because we were able to address consumer complaints by calling the General Manager [of the bank]... [and] [regulating through] signalling effect. $^{20}$

The statement reflects the regulators' belief in micro-level regulatory actions and the rationale behind not introducing a formal regulation that could have addressed persistent consumer complaints with an across-the-board binding regulation on the regulatee. The statement also implies that the regulators believed in self-regulation and tried to address consumer complaints with moral suasion.

Further, the regulators and bankers have a shared belief in self-regulatory markets. A senior banker mentions that "the regulations are against the logic of a liberal economy." ${ }^{21}$ Another senior banker says "[I]n a free market, the authority should not set a particular price on any service." ${ }^{22}$ Reflecting the common ideational approach, a senior regulator mentions that "it is 
very difficult to find out a fair amount because each bank is running its own business according to its revenue and cost model." ${ }^{, 3}$ A common ideological stance points to the two actors' belief in self-regulation, which leads to a non-interventionist policy stance. Such stance was reinforced with the BRSA interpreting its mandate as not giving the regulatory agency a legal mandate to monitor financial consumer protection. Although it was not remaining idle, the BRSA was trying to address consumer complaints through ineffective moral suasion.

Here, a policy regime can achieve monopoly over a given policy issue not only because of regime reinforcing institutional arrangements and shared ideational orientation. What is more, organisational incapacity of the BRSA and institutional impediments arising from other policy areas are complementary factors in sustaining that monopoly. A banker describes why the banking sector failed to self-regulate as a whole if not at the individual bank level

the Banks' Association [and individual banks] could not have done anything on their own because regulating fees, commissions, and charges would have meant collusion, price fixing, which is against competition policy ... The Association cannot determine the price. This never happened. ${ }^{24}$

The statement indicates that the sector was caught between addressing a persistent consumer concern and being accused of price fixing if it were to self-regulate. On the BRSA's side, a regulator emphasises that "[It took time for the BRSA to act on the issue] because I think this is a natural process. As human resource quality improves, you can act on certain issues more easily." 25 This then shows that the BRSA's organisational incapacity to steer prudential banking regulation resonated in the financial consumer protection as well (Bakir and Öniş 2010, 101). 
All in all, shared belief in self-regulatory markets, an exclusionary policymaking process as well as institutional impediments and lack of adequate organisational capacity led to regulatory forbearance. This then forced the consumer groups to mobilise consumers and appeal to a strategic, resourceful ally to contest the policy regime and its non-interventionist policy approach.

\section{Consumer Groups: Mobilisation and Lobbying}

For mobilisation, issue salience needs to reach a certain threshold to force actors to mobilise. The rise in issue salience among consumers and the consumer groups had two sources. The first relates to financial deepening with more participation of households in the financial system. The number of individuals with outstanding consumer loans provide an insight about how issue salience regarding fees, commissions, and charges increased. Figure 3 indicates that there were 3.5 million individuals with outstanding consumer loans in 2004 , which rose to around 19.5 million by 2015 . The rise in the number of individuals underlines that the interaction between financial consumers and the banking sector has intensified in the last decade. When this is considered in the light of banks becoming reliant on retail banking fees, commissions, and charges, and charging previously uncharged services, more use of retail banking services caused a surge in issue salience among consumers. 
Figure 3: Number of individuals with outstanding loans, 2004-2015

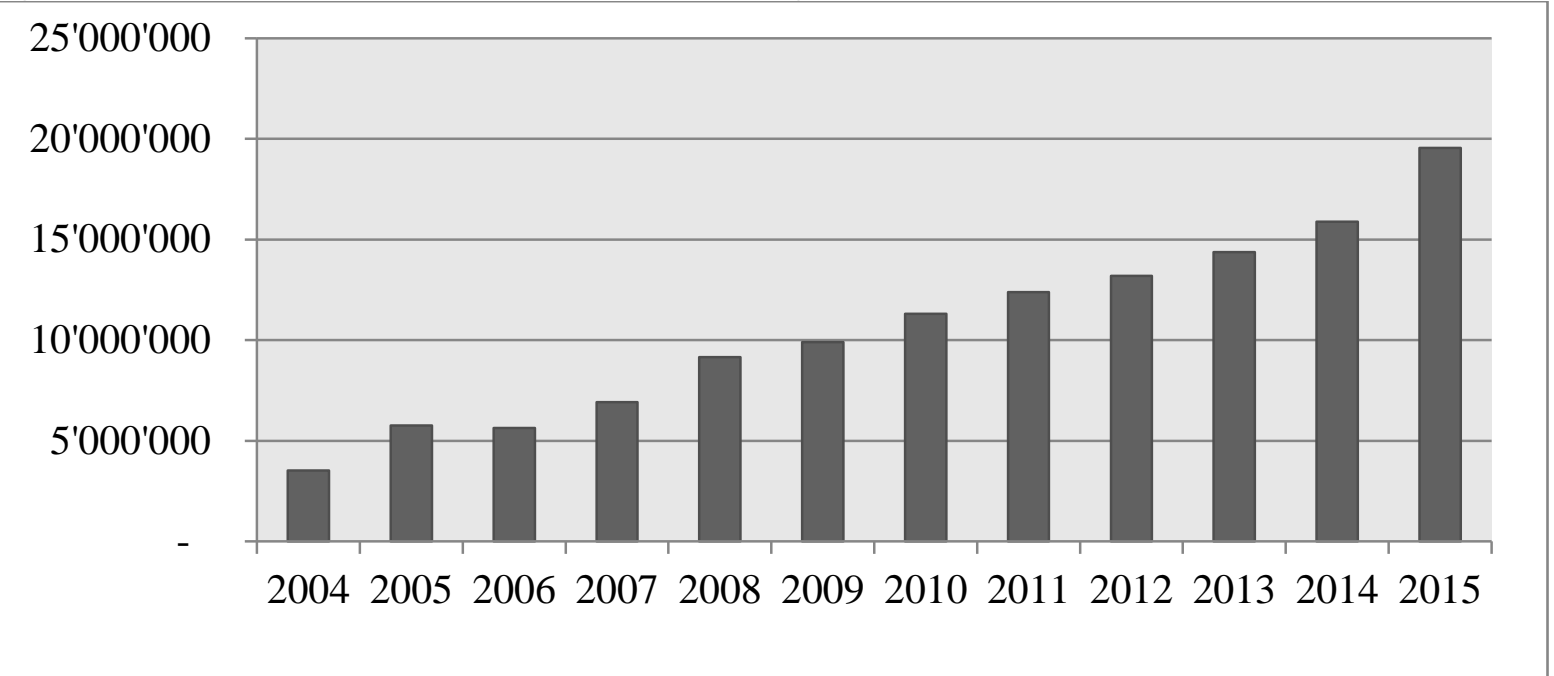

Source: The Banks' Association of Turkey, author's compilation.

The second important source of the surge in issue salience emerged with enactment of the Housing Finance Law enacted in $2007 .{ }^{26}$ A representative of a consumer group explains this as "housing finance loans were treated differently than consumer loans with the Housing Finance Law. It enabled banks to attach these loans additional services such as insurance... Also, a charge on early payments is included in the Law [Housing Finance Law]. ${ }^{, 27}$

As issue salience rose, consumer groups began to mobilise. For this, they relied mainly on outsider tactics. These included press briefings, demonstrations in front of the headquarters of the Banks' Association of Turkey, organising conferences and panels and collaborating with other non-governmental organisations and experts specialised in banking and consumer protection law so as to be informed about the technicalities of financial consumer protection and retail banking services. Moreover, in contrast to the expectations of the literature as diffuse interest groups tend to use media as an important channel (Binderkrantz 2008), the consumer group representatives agree that the media channel is essential, but is not very effective given low coverage. A consumer representative claims that "media coverage is an essential channel for us to exert influence over other parties but it is selective in its reports, 
and may sometimes misrepresent our messages, which reduces its impact."28 The interviews with the representatives reveal that those activities had a very negligible effect to trigger policy change.

Meanwhile, consumer groups faced serious limitations to trigger policy change on their own. Consumer groups also lacked sufficient human and financial resources to contest the policy regime. Turkey is a country where individuals are wary of mass mobilisation. This originates from "distrust [of state actors] toward societal interests. ...[And] organized societal actors... were de jure prohibited [in the Constitution until amendments in 1995] from engaging in political activity" (Bolukbasi and Ertugal 2018, 365-366, emphasis in original). Engaging in such activities therefore might mean criminalisation and indictment. Reflecting these limits on taking part in interest group politics, the interviewed consumer group officials mention that it is very difficult to recruit members because individuals are either uninterested in or are afraid of being a member of a collective effort. This reduces the number of individuals taking part in interest group activities. A consumer group official mentions that "there are 3-5 members in each commission in charge of an issue [we are working on]. The unsteady participation level impedes accumulation of know-how [and expertise on a given issue], therefore the effectiveness of mobilisation and lobbying declines." 29

Furthermore, consumer group representatives mention lack of sustainable funding. A consumer group representative mentions that "our annual membership fee is only 18 liras per year. Some members are loyal, but some are not paying on a permanent basis. ... When we assist individual consumers [when preparing documents to place complaints] we charge them around 20 to 30 liras. We are asking for payments because if we do not, we will have to close down. ... [Additionally,] we do not receive funds from the state or other donors. ${ }^{, 30}$ 
In light of the above factors, given the exclusionary policymaking process sustained by the policy regime along with the "statist" policy style, it is legitimate to expect the consumer groups to search for arenas for outside lobbying to expand the conflict zone by bringing in influential allies for their voice could be heard. Within such a policymaking context, consumer groups undoubtedly had to appeal to another state actor: the Minister of Customs and Trade. A consumer group representative mentions that "[S]ince the BRSA was not talking to us, we tried to influence the Ministry. We did so by using arenas such as the Consumer Council and other meetings (e.g. conferences, panels, individual meetings with the Minister).",31

Getting the Ministry as an ally was crucial for consumer groups for three reasons. First, the Ministry has a mandate to supervise firms in the Turkish economy in consumer protection. However, the Ministry could not supervise the banking sector in particular retail banking fees, commissions, and charges, as the previous versions of the Law did not have clauses on that particular area. Thus, by attracting the Ministry's attention, the Ministry would have included that area in further legislation.

Second, the Ministry and the BRSA do not share a common policy image of regulating retail banking fees, commissions, and charges. For the Ministry, banking is an ordinary commercial activity. On the contrary, the BRSA perceives a particular financial organization when it imagines a bank. ${ }^{32}$ Here, regulatory stance diverges on how to regulate a non-financial firm and a bank. The BRSA is more interested in profitability and the role of the banking sector in the economy given its mandate to sustain profitability of the sector while overseeing financial stability and financial development. In contrast, the Ministry concentrates more on consumer welfare. 
Third, a representative of a consumer group asserts that "the ultimate decision lies with the politicians. ${ }^{33}$ Here, a ministry, in the Turkish context, has the capacity to propose laws that can complement or contradict mandates of independent regulatory agencies. Thus, a ministry has an upper hand vis-à-vis a regulatory agency; and by capitalising on its capacity to initiate enactment of a law, it can force the regulatory agency to adopt certain practices.

Therefore, by taking advantage of a variation in policy image and capitalising on the power of the executive over the BRSA through the Ministry, consumer groups had to attract the Ministry's attention on the issue. To do so, they benefitted from two channels. First, the amendment to the 1995 version of the Law was in 2003, and had established a consumer arbitration panel system. The arbitration system operates under the auspices of the Ministry. The decisions of the arbitration panels are obligatory. Uzunoğlan reports that the share of complaints about the banking sector in a total number of complaints appealed to the Ministry has risen from 25 percent in 2009 to 72 percent in 2013 where the total number of complaints was 833,854 in 2013 compared to 143,810 in 2009 (Uzunoğlan 2015). ${ }^{34}$ The senior official in the Ministry asserts that "the share of consumer complaints have become so concentrated on the banking sector that it constituted the main reason why the Ministry acted on this issue., ${ }^{, 35}$ The rise was partly driven by consumer groups' conducting information campaigns to make consumers more aware of the arbitration panel system. Also, the interviewed consumer group representatives mention that they assist consumers to prepare legal documents to place complaints to the arbitration panel.

Second, the Ministry organises the Consumer Council (Tüketici Konseyi, in Turkish) each year. A day-long Council meeting ends with a communiqué. ${ }^{36}$ The Consumer Council meetings provide a forum for discussion of consumers' concerns. Although the Consumer 
Council communiqué does not have a binding power, consumer groups were able to contest the banking sector in the Council as the Banks' Association of Turkey attends the meeting. Attending the Council meetings provided a conducive environment for them to raise voice and contest the Banks' Association of Turkey at a meeting in which the Minister or the Chair of the Council appointed by the Minister participates. These channels were important for consumer groups because the communiqués of the Consumer Council indicate that financial consumer protection has become frequently pronounced particularly after 2007. More importantly, since consumer groups have inadequate financial and human resources to lead policy change out of their own effort, using the consumer arbitration panel, Consumer Council and individual meetings with the Minister allowed them to use their limited resources in a more efficient way, and finally achieve attracting a powerful, resourceful, and strategic actor's attention on the policy problem.

\section{Consumer Groups, the Minister, and the New Consumer Protection Law}

After the June 2011 general elections, Hayati Yazıc1, a close friend and lawyer of Erdogan even before him becoming the Prime Minister in 2003, became the Minister of Customs and Trade after the June 2011 general elections, and stayed in that position until 2014. His close relations with and 'access' to the then-Prime Minister Erdogan could be argued to have politically capacitated the Minister and provided him and the Ministry the necessary legitimate support of the government to address consumer demands. Yazıcı's critical role in this regard is emphasised by a senior banker as "if the Minister was not [Hayati] Yazıc1, the content of the Consumer Protection Law and the regulation could have had a softer approach. ${ }^{37}$ Soon after he became the Minister, Yazıcı stated that the 2003 version of the Law was not meeting the standards and needs of the Turkish economy in March 2012. To address that gap, the Ministry drafted a new law to update the existing Law with a new 
version. The new law also aimed to make the local consumer protection framework compliant with the EU regulatory standards, namely the $28^{\text {th }}$ Chapter of the EU acquis, ${ }^{38}$ which oversees consumer and health protection in broad terms. As part of the accession process, Turkey had to comply with the acquis. Admittedly, the EU acquis does not involve particular clauses on financial consumer protection in retail banking fees, commissions, and charges. However, such opportunity structures provide legitimate reference points to challenge enduring policy ideas and institutional arrangements. As such, compliance with the acquis had an enabling role for the Ministry to capitalise that particular opportunity to address consumers' demands for regulation of retail banking fees, commissions, and charges.

Here, the Minister's attention and addressing consumer demands in the 2013 version of the Law were driven by consumer complaints and consumer groups' lobbying the Minister and his bureau. Following a meeting with the representatives of two largest consumer groups in terms of membership (the Consumer Rights Association, THD in Turkish, and the Federation of Consumer Associations, TUDEF in Turkish) in March 2012, Yazıc1 announced that the high (and rising) number of consumer complaints submitted to the consumer arbitration panels and the judiciary's decisions on various cases demonstrated the need for a regulation. We can infer this from his statement on the need for regulation following a meeting with consumer group representatives. The minutes of the meeting are not publicly accessible. Yet we can still claim that consumer groups' appeal to the Minister was critical for him to recognise the necessity of a regulation that was addressed in the new version of the Law. Yazıc1 mentioned in 2013 that consumer complaints to the Ministry were 446,054, 263,428 of which were related to banking sector in 2012. By the end of April 2013, out of 195,314 complaints, 135,525 were related to the banking sector, which means the share of complaints about the banking sector in the whole sample was 59 percent in 2013. By 2014, this increased 
to 68 percent. ${ }^{39}$ Most importantly, the figures he refers to imply the impact of the number of consumer complaints on why he prioritises the policy issue and how he conceptualises the problem issue. Moreover, he states during the negotiations of the Law in the National Assembly in 2013 that the Law is a concern for all citizens and the discussion in the National Assembly should take into account concerns about consumer protection in regards to retail banking fees, commissions, and charges. ${ }^{40}$ Besides the impact of consumer complaints, his statement indicates the difference in policy images the Minister and the regulators had about regulating retail banking fees, commissions, and charges.

While consumer complaints and consumer groups' lobbying provided societal force to attract the Ministry's attention, and compliance with the EU acquis constituted an opportunity structure to challenge the policy regime of the BRSA and the Turkish banking sector was facilitated by the institutional environment within which the Turkish bureaucracy is organised. It is known in the Turkish bureaucracy that public organisations try to exploit opportunities to "occupy" other organisations' mandated policy areas, in other words expand their bureaucratic turf (Allison 1971; Wilson 1990), especially if the designated area is 'unoccupied' by the mandated organisation. As put by a regulator "[p]ublic sector does not allow policy areas to remain unoccupied. If no one is occupying a particular area ... someone will grab that area and you can no longer claim that space anymore."

In this regard, regulatory forbearance provided a fruitful ground for the Minister and his bureaucracy to fill the gap by including measures on banking and financial services in the Law. Despite lacking human resources in the form of officials specialised in banking and finance, ${ }^{42}$ the new version of the Law has strengthened the role of the Ministry in the regulation of fees, commissions, and charges. This is because the new version of the Law 
meant empowerment of the Ministry, as it is owned by the Ministry. To "own a law", means that the Ministry holds the sanctioning power in spite of the active role of the BRSA in preparation and implementation of the regulation. This is observable in the role attributed to the Ministry in supervision of compliance of the banking sector with the regulation. Article 4(3) requires the BRSA to regulate retail banking fees, commissions, and charges in liaison with the Ministry but Article 75 assigns a supervisory role for the Ministry to control compliance with the Law. Thus, relying on its supervisory power, the Ministry has begun onsite inspections in the banking sector, and even utilising its sanctioning power in cases of noncompliance with the Law.

\section{Concluding Remarks}

This article examined why and how a regulation on retail banking fees, commissions, and charged emerged in 2014 after a decade of persistent consumer complaints which failed to produce concrete policy measures before. The article demonstrates that despite contextual and organisational challenges, consumer groups, with the help of a strategic, resourceful ally within the state apparatus in a state-centric policymaking process and context, the Minister and his bureau, achieved to challenge the policy regime of the banking sector and the BRSA. At the same time, this allowed consumer groups to keep the BRSA accountable to themselves (see Koop 2011).

Consumer group mobilisation and lobbying provided the necessary but insufficient stimulus that led to the involvement of the Ministry in financial consumer protection. The involvement of the Ministry in the policymaking process, while exploiting an opportunity structure, materialised a policy paradigm shift from a "light touch" approach to a stricter approach, change in institutional arrangements with its emergence as an essential veto player. 
Regulatory policy change could not have been possible unless the policy regime remained intact. As such, policy regime change embodies the emergence of the Ministry as a veto player veto withsactioning power, and influence over the BRSA and the regulatee. Such capability did not exist before policy regime change. Moreover, consumer groups gained access to the policymaking process.

The findings are in line with studies that point to the impactful role of diffuse interest groups in the policymaking context, how outsider tactics can help diffuse interest groups, and the key role of existence of resourceful, responsive allies or their lack thereof regardless of political regimes be they liberal or authoritarian in triggering policy change and even policy regime change (Kastner 2017; Van Rooij 2010; Van Rooij, Stern, and Fürst 2016; Yagci 2019). In addition, the article points to effective use of mix of insider and outsider tactics. However, the questions of how and when they are used direct us to the need for further examination of the reasons why one tactic fails, why distinct actors are (ir)responsive to diffuse interest group demands, and the institutional arrangements that structure the policymaking process.

Here, Binderkrantz and Pedersen (2019) argue that diffuse interest groups are more influential in setting the agenda, whereas concentrated interest groups concentrate on the decisionmaking stage. In this light, the interviewed bankers, regulators, and the official in the Ministry provided a common view on this point: the regulation reflects the limited role of the banking sector depite its active participation in the regulatory design stage after the the Law entered into force in 2013. A banker says "[T]he banking sector participated in actively in the whole process from lawmaking to regulatory policy design. But, we cannot claim we got what we wanted. Our impact was limited." 43 Another banker adds that "the extent of our influence on the content of the regulation was around 10-15 percent, not more than that. And, this was 
mostly on avoiding a cap on fees and commissions and a lower cap on early loan payments. ${ }^{\prime 44}$ Moreover, most of the bankers complained about the regulation as it had a negative impact on revenue generation and thereby profitability. As a result, the banking sector began to place requests to the BRSA to update the list of chargeable items with the aim of including several more items after the introduction of the regulation. A regulator notes that "some banks and non-financial intermediaries have placed their requests to add new items to the list ... but we said we cannot change the regulation." $" 45$

Finally, the article presents two important avenues for future research, which have broader implications. Firstly, even though we might expect regime actors to share a similar regulatory approach, which might supposedly apply to any pillar of the same policy sector, one might wonder whether the policy regime actors might have diverging preferences across policy areas; and whether or not there are spillovers across policy areas, which might affect the policymaking processes in distinct policy areas. ${ }^{46}$ Secondly, research on regulatory agency independence underlined that agency independence is not only related to de jure independence. A regulatory agency operates in a regulatory space that hosts multiple actors such as civil society organisations, private sector actors, co-regulators, and peer public organisations (Ingold et al 2013; Maggetti and Papadopoulos 2016). The article demonstrates that intra-bureaucratic interactions within the state apparatus can limit de facto independence of an independent regulatory agency. (Maggetti 2007). This then calls our attention to how an independent agency could balance its relations with various actors it interacts with in the same regulatory space, and how it could maintain de facto independence in case of challenges posed by other public organisations and even non-state actors. 


\section{References}

Akinbami, F. 2011. Financial Services and Consumer Protection after the Crisis. International Journal of Bank Marketing 29(4): 134-147.

Albareda, A. 2018. Connecting Society and Policymakers? Conceptualizing and Measuring the Capacity of Civil Society Organizations to Act as Transmission Belts. Voluntas 29(6): 1216-1232.

Allison, G.T. 1971. The Essence of Decision: Explaining the Cuban Missile Crisis. Glenview, Ill: S. Foresman.

Anheier, H.K. 2014. Institutional Voids and the Role of Civil Society: The Case of Global Finance. Global Policy 5(1): 23-35.

Aricanli, T., and D. Rodrik. 1990. An Overview of Turkey's Experience with Economic Liberalization and Structural Adjustment. World Development 18(10): 1343-1350.

Bakir, C. 2015. Bargaining with Multinationals: Why State Capacity Matters. New Political Economy 20(1): 63-84.

Bakir, C., and Z. Öniș. 2010. The Regulatory State and Turkish Banking Reforms in the Age of post-Washington Consensus. Development and Change 41(1): 77-106.

Baumgartner, F.R. 1996. Public Interest Groups in France and the United States. Governance 9(1): 1-22.

Baumgartner, F.R., and B.D. Jones. 1991. Agenda Dynamics and Policy Subsystems. The Journal of Politics 53(4): 1044-1074.

Baumgartner, F.R., and B.D. Jones. 1993. Agendas and Instability in American Politics. Chicago, Ill: The University of Chicago Press.

Baumgartner, F.R. et al. 2009. Lobbying and Policy Change: Who Wins, Who Loses, and Why. Chicago, Ill: University of Chicago Press.

BRSA. 2014. Finansal Tüketicinin Korunması Eylem Planı: Arka plan Belgesi [The Action Plan for Financial Consumer Protection: The Background Paper]. Ankara: Banking Regulation and Supervision Agency.

Becker, G.S. 1983. A Theory of Competition among Pressure Groups for Political Influence. The Quarterly Journal of Economics 98(3): 371-400.

Beyers, J. 2004. Voice and Access: Political Practices of European Interest Associations. European Union Politics 5(2): 211-240.

Binderkrantz, A.S. 2005. Interest Group Strategies: Navigating between Privileged Access and Strategies of Pressure. Political Studies 53(4): 694-715.

Binderkrantz, A. 2008. Different Groups, Different Strategies: How Interest Groups Pursue their Political Ambitions. Scandinavian Political Studies 31(2): 173-200.

Binderkrantz, A.S. and S. Krøyer. 2012. Customizing Strategy: Policy Goals and Interest Group Strategies. Interest Groups \& Advocacy 1(1): 115-138.

Binderkrantz, A.S., P.M. Christiansen, and H.H. Pedersen. 2015. Interest Group Access to the Bureaucracy, Parliament, and the Media. Governance 28(1): 95-112.

Binderkrantz, A.S., and H.H. Pedersen. 2019. The Lobbying Success of Citizen and Economic Groups in Denmark and the UK. Acta Politica 54(1): 75-103.

BloombergHT. 2015. Ticaret Bakanlığı'ndan Bankalara Denetim [The Ministry of Trade Supervises the Banks]. November 24. Retrieved from https://www.bloomberght.com/haberler/haber/1831816-ticaret-bakanligindanbankalara-denetim.

Blyth, M. 1997. "Any More bright Ideas?" The Ideational Turn of Comparative Political Economy. Comparative Politics 29(2): 229-250.

2002, The Great Transformations: Economic Ideas and Institutional Change in the Twentieth Century. New York, NY: Cambridge University Press. 
Bolukbasi, H.T., and E. Ertugal. 2018. Napoleonic Traditions, Majoritarianism, and Turkey's Statist Policy Style. In Policy Styles and Policy-making: Exploring the Linkages, ed. M. Howlett, and J. Tosun, 351-374. London: Routledge.

Coban, M.K. 2019. Compliance Forces, Domestic Policy Process, and International Regulatory Standards: Compliance with Basel III. Business and Politics 22(1): 161195.

Culpepper, P.D. 2010. Quiet Politics and Business Power: Corporate Control in Europe and Japan. New York, NY: Cambridge University Press.

Culpepper, P.D. 2015. Structural Power and Political Science in the Post-crisis Era, Business and Politics 17(3): 391-409.

De Bruycker, I. 2019. Blessing or Curse for Advocacy? How News Media Attention Helps advocacy Groups to Achieve their Policy Goals. Political Communication 36(1): 103126.

De Bruycker, I., and J. Beyers. 2019. Lobbying Strategies and Success: Inside and Outside Lobbying in European Union Legislative Politics. European Political Science 11(1): 57-74.

Delacote, D. 2009. On the Sources of Consumer Boycotts Ineffectiveness. The Journal of Environment \& Development 18(3): 306-322.

Downs, A. 1972. Up and Down with Ecology - the "Issue-attention Cycle". The Public Interest 28: 38-50.

Dür, A. 2008. Interest Groups in the European Union: How Powerful are They? West European Politics 31(6): 1212-1230.

Dür, A. 2019. How Interest Groups Influence Public Opinion: Arguments Matter More than the Sources. European Journal of Political Research 58(2): 514-535.

Dür, A., and D. De Bièvre. 2007. The Question of Interest Group Influence. Journal of Public Policy 27(1): 1-12.

Dür, A., and G. Mateo. 2013. Gaining Access or Going Public? Interest Group Strategies in five European Countries. European Journal of Political Research 52(5): 660-686.

Dür, A., and G. Mateo. 2014. Public Opinion and Interest Group Influence: How Citizen Group Derailed the Anti-counterfeiting Trade Agreement. Journal of European Public Policy. 21(8): 1199-1217.

Flöthe, L. 2019. Representation through Information? When and Why Interest Groups Inform Policymakers about Public Preferences. Journal of European Public Policy. DOI: 10.1080/13501763.2019.1599042.

Gezder, Ü. 2006. Consumer Protection in Turkey and Distance Contracts. Annales de la Faculté de Droit d'Istanbul 38(55): 191-209.

Gordon, S.C., and C. Hafer. 2014. Conditional Forbearance as an Alternative to Capture. In Preventing Regulatory Capture: Special Interest Influence and How to Limit It, ed. D. Carpenter, and D.A. Moss, 208-238. Cambridge, MA: Cambridge University Press.

Hajnocki, M. et al. 2012. Studying Organizational Advocacy and Influence: Reexamining Interest Group Research. Annual Review of Political Science 15:379-399.

Halpin, D.R., and B. Fraussen. 2017. Conceptualising the Policy Engagement of Interest Groups: Involvement, Access and Prominence. European Journal of Political Research 56(3): 723-732.

Hirschman, A.O. 1970. Exit, Voice, and Loyalty: Responses to Decline in Firms, Organizations, and States. Cambridge, MA: Harvard University Press.

Hilton, M. 2009. Prosperity for All: Consumer Activism in an Era of Globalization. Ithaca. NY: Cornell University Press.

Hochstetler, K. 2012. Civil Society and the Regulatory State of the South: A Commentary. Regulation \& Governance 6(3): 362-370. 
IMF. 2000. Turkey: Selected Issues and Statistical Appendix. IMF Staff Country Report, No. 00/14. Washington, DC: International Monetary Fund.

Ingold, K., F. Varone, and F. Stokman. 2013. A Social Network-based Approach to Assess De Facto Independence of Regulatory Agencies. Journal of European Public Policy 20(10): 1464-1481.

Jochim, A.E., P.J. May. 2010. Beyond Subsystems: Policy Regimes and Governance. Policy Studies Journal 38(2): 303-327.

Kastner, L. 2014. 'Much Ado About Nothing?' Transnational Civil Society, Consumer Protection and Financial Regulatory Reform. Review of International Political Economy 21(6): 1313-1345.

Kastner, L. 2017. Tracing Policy Influence of Diffuse Interests: The Post-crisis Consumer Finance Protection Politics in the US. Journal of Civil Society 13(2): 130-148.

Kastner, L. 2019. From Outsiders to Insiders: A Civil Society Perspective on EU Financial Reforms. Journal of Common Market Studies 57(2): 223-241.

Kollman, K. 1998. Outside Lobbying: Public Opinion and Interest Group Strategies, Princeton, NJ: Princeton University Press.

Koop, C. 2011. Explaning the Accountability of Independent Agencies: The Importance of Political Salience. Journal of Public Policy 31(2): 209-234.

Kriesi, H., A. Tresch, M. Jochum. 2007. Going Public in the European Union: European Collective Political Actors. Comparative Political Studies 40(1): 48-73.

Kwak, J. 2014. Cultural Capture and the Financial Crisis. In Preventing Regulatory Capture: Special Interest Influence and How to Limit It, ed. D. Carpenter, and D.A. Moss, 7198. Cambridge, MA: Cambridge University Press.

Laffont, J., and J. Tirole. 1991. The Politics of Government Decision-making: A Theory of Regulatory Capture. The Quarterly Journal of Economics 106(4): 1089-1127.

Lindblom, C.E. 1977. Politics and Markets: The World's Political Economic Systems New York, NY: Basic Books.

Maggetti, M. 2007. De Facto Independence after Delegation: A Fuzzy-set Analysis, Regulation \& Governance 1(4): 271-294.

Maggetti, M., and Y. Papadopoulos. 2018. The Principal-agent Framework and Independent Regulatory Agencies. Political Studies Review 16(3): 172-183.

Mahoney, C. 2007. Lobbying Success in the United States and the European Union. Journal of Public Policy 27(1): 35-56.

Maloney, W.A., G. Jordan, A.M. McLaughlin. 1994. Interest Groups and Public Policy: The Insider/outsider Model Revisited. Journal of Public Policy 14(1): 17-38.

May, P.J., and A.E. Jochim. 2013. Policy Regime Perspectives: Policies, Politics, and Governing. Policy Studies Journal 41(3): 426-452.

McAdam, D., S. Tarrow, and C. Tilly. 1996. To Map Contentious Politics. Mobilization: An International Journal 1(1): 17-34.

McAdam, D., S. Tarrow, and C. Tilly. 2001. Dynamics of Contention. Cambridge: Cambridge University Press.

Meyer, D.S. 2004. Protest and Political Opportunities. Annual Review of Sociology, 30:125145.

Meyer, D.S., and D.C. Minkoff. 2004. Conceptualizing Political Opportunity. Social Forces 82(4): 1457-1492.

Offe, C. 1985. New Social Movements: Challenging the Boundaries of Institutional Politics. Social Research 52(4): 817-868.

Olson, M. 1965. The Logic of Collective Action: Public Goods and the Theory of Groups. Cambridge, MA: Harvard University Press. 
Pagliari, S., and K. Young. 2016. The Interest Ecology of Financial Regulation: Interest Group Plurality in the Design of Financial Regulatory Policies. Socio-Economic Review 14(1): 309-337.

Peltzman, S. 1976. Toward a More General Theory of Regulation. Journal of Law and Economics 19(2): 211-240.

Pierson, P. 2000. Increasing Returns, Path Dependence, and the Study of Politics. The American Political Science Review 94(2): 251-267.

Rhee, K., and J. Lee. 1996. Review of Consumer Activism in Korea, 1910-1995: A PoliticalEconomic Approach. Journal of Consumer Policy 19(3): 365-392.

Schattschneider, E.E. 1975[1960]. The Semisovereign People: A Realist's view of Democracy in America. Hinsdale, Ill: Dryden Press.

Schuck, P.H. 1977. Public Interest Groups and the Policy Process. Public Administration Review 37(2): 132-140.

Steurer, R. 2013. Disentangling Governance: A Synoptic View of a Regulation by Government, Business and Civil Society. Policy Sciences 46(4): 387-410.

Stigler, G.J. 1971. The Theory of Economic Regulation. Bell Journal of Economics and Management Science 2(1): 3-21.

Thrall, T. 2006. The Myth of the Outside Strategy: Mass Media News Coverage of Interest Groups. Political Communication 23(4): 407-420.

Trumbull, G. 2012. Strength in Numbers: The Political Power of Weak Interests, Cambridge, MA: Harvard University Press.

Uzunoğlan, B. 2015. Bankacılık Sektöründe Tüketicilerin Korunması, Yaşanan Sorunlar ve Çözüme Yönelik Bakanlığımızca Yapilan Faaliyetler [Consumer Protection in the Banking Sector, the Problems and the Ministry's Activities for Problem Resolution]. In Bankacılık Sektöründe Tüketici Hukuku Uygulamalarl [The Application of Consumer Law in the Banking Sector], ed. H. Tokbaş, and A.S. Kurşun, 7-28. Ankara: Aristo Yayınları.

Van Rooij, B. 2010. The People vs. Pollution: Understanding Citizen Action against Pollution in China. Journal of Contemporary China 19(63): 55-77.

Van Rooij, B., R.E. Stern, and K. Fürst. 2016. The Authoritarian Logic of Regulatory Pluralism: Understanding China's New Environmental Actors. Regulation \& Governance 10(1): 3-13.

Weiler, F., and B. Brandli. 2015. Inside versus Outside Lobbying: How the Institutional Framework Shapes the Lobbying Behaviour of Interest Groups. European Journal of Political Research 54(4): 745-766.

Weiler, F., S. Eichenberger, A. Mach, and F. Varone. 2019, More Equal than Others: Assessing Economic and Citizen Groups' Access across Policymaking Venues. Governance 32(2): 277-293.

Wilson, C.A. 2000. Policy Regimes and Policy Change. Journal of Public Policy 20(3): 247274.

Wilson, J.Q. 1990. Bureaucracy: What Government Agencies Do and Why They Do It. New York, NY: Basic Books.

Yagci, A. 2019. Policy Knowledge, Collective Action and Advocacy Coalitions: Regulating GMOs in Turkey. Journal of European Public Policy 26(6): 927-945.

Ziegler, J.N., and J.T. Wolley. 2016 After Dodd-Frank: Ideas and Post-enactment Politics of Financial Reform in the United States. Politics \& Society 44(2): 249-280. 


\section{Notes:}

${ }^{1}$ The "statist" policy style can surely limit the degree of influence of concentrated interest groups (i.e., private sector) in the policymaking process as well (see Bakir 2015). The article focuses solely on diffuse interest groups, and emphasises how the "statist" policy style limits diffuse interest group representation in the policymaking process.

${ }^{2}$ The Consumer Protection Law No. 6502, published in the Official Gazette on November 28, 2013.

${ }^{3}$ Article 4(3) of the Consumer Protection Law No 6502.

${ }^{4}$ I am grateful to Tolga Bolukbasi to point out this critical point.

${ }^{5}$ Regulation on the Principles and Procedures to the Fees Obtained from Financial Consumers, published in the Official Gazette on October 3, 2014. Available in Turkish https://www.bddk.org.tr/WebSitesi/turkce/Mevzuat/Finansal_Tuketicinin_Korunmasina_Iliskin_Duzenlemeler/1 358623_aralik_2017_degisikligi.pdf, accessed on January 20, 2018.

${ }^{6}$ Regulatory forbearance stems from regulators' disregard of a policy issue in the form of non-compliance to the legal mandate of the organisation, selective implementation of the mandate, or, the regulators might perceive that they lack a mandate to act upon a given policy issue. Regulatory forbearance is conditional on two factors: the identity of the agency's political principal, and issue salience (Gordon and Hafer, 2014, 209). While the former can affect how and whether or not the principal monitors the agency's behaviour in light of its performance, the second relates more to the agency's accountability to citizens.

${ }^{7}$ A consumer group is a particular type of diffuse interest group (Schuck 1977, p. 133) as “...[they] pursue policy outcomes grounded in their collective material interests" (Trumbull 2012, p. 10). Consumer groups have a disorganised and network-based organisational structure, and are ad-hoc groups that involve groups of individuals working through networks on a voluntary basis (Offe 1985). They operate within the market and sought state intervention to prevent harm on social/consumer welfare (King and Pearce 2010).

${ }^{8}$ Maloney et al. (1994) rightly point to conflation of the insider/outsider divide in the literature. Studies apply the divide either when referring to the status of an interest group in the policymaking process or to groups' strategies. This article refers to groups strategies, but at the same time considers that the position of a group in the policymaking process enforces certain strategies.

${ }^{9}$ Consumer Protection Law No. 4077, published in the Official Gazette on March 8, 1995. Available in Turkish at:

http://www.resmigazete.gov.tr/main.aspx?home=http://www.resmigazete.gov.tr/arsiv/22221.pdf\&main=http://w ww.resmigazete.gov.tr/arsiv/22221.pdf, accessed on February 25, 2018.

${ }^{10}$ Law on the Changes in the Consumer Protection No. 4822, published in the Official Gazette on March 14, 2003. Available in Turkish

http://www.resmigazete.gov.tr/main.aspx?home=http://www.resmigazete.gov.tr/eskiler/2003/03/20030314.htm/2 0030314.htm\&main=http://www.resmigazete.gov.tr/eskiler/2003/03/20030314.htm, accessed on February 25,

2018.

${ }^{11}$ See note 3 .

12 See note 5 .

${ }^{13}$ Interview, R2, BRSA, Istanbul, February 19, 2016.

14 See his speech, http://www.hurriyetdailynews.com/lower-profits-may-increase-banksfees.aspx? pageID=238\&nID=7866\&NewsCatID=346, accessed on December 5, 2017.

${ }^{15}$ Interview, B5, T. Is Bank, Istanbul, March 1, 2016.

${ }^{16}$ Interview, R4, BRSA, Istanbul, March 4, 2016.

${ }^{17}$ Interview, C3, Consumer Associations Federation (TOFED), Istanbul, February 13, 2016.

${ }^{18}$ Interview, C2, Consumer Rights Association (THD), Ankara, January 27, 2016.

${ }^{19}$ Banking Law No 5411, published in the Official Gazette on November 19, 2005.

${ }^{20}$ Interview, R1, BRSA, Istanbul, March 4, 2016.

${ }^{21}$ Interview, B9, TEB, Istanbul, February 8, 2016.

${ }^{22}$ Interview, B3, T. Is Bank, Istanbul, February 24, 2016.

${ }^{23}$ Interview, R3, BRSA, Ankara, January 21, 2016.

${ }^{24}$ Interview, B3, T. Is Bank, Istanbul, February 24, 2016.

${ }^{25}$ Interview, R3, BRSA, Ankara, January 21, 2016.

${ }^{26} 5582$ sayıl1 Konut Finansmanı Kanunu [Housing Finance Law No. 5582], published in the Official Gazette on March 6, 2007.

${ }^{27}$ Interview, C1, Consumer and Environment Foundation (TUKCEV), Ankara, January 20, 2016.

${ }^{28}$ Interview, C2, Consumer Rights Association (THD), Ankara, January 27, 2016.

${ }^{29}$ Interview, C2, Consumer Rights Association (THD), Ankara, January 27, 2016.

${ }^{30}$ Interview, C3, Consumer Associations Federation (TOFED), Istanbul, February 13, 2016. 
${ }^{31}$ Interview, C3, Consumer Associations Federation (TOFED), Istanbul, February 13, 2016.

${ }^{32}$ Interview, R4, BRSA, Ankara, January 11, 2016.

${ }^{33}$ Interview, C1, Consumer and Environment Foundation (TUKCEV), Ankara, January 20, 2016.

${ }^{34}$ The Banks' Association of Turkey can also handle consumer complaints, but has a passive role. The Association can only request a feedback on consumers' complaints from a bank. If the bank opts for inaction despite the Association's demand, the Association cannot sanction the bank.

${ }^{35}$ Interview, M1, Ministry, Ankara, March 28, 2016.

36 The communiqués of the Council are available in Turkish http://www.tuketici.gov.tr/index.snet?wapp=konseykararlari_tr\&open=6, accessed on January 10, 2017.

${ }^{37}$ Interview, B9, TEB, Istanbul, February 8, 2016.

${ }^{38}$ Interview, M1, Ministry, Ankara, January 14, 2016.

39 The Minister's speech is available in Turkish https://www.gtb.gov.tr/haberler/yazici-bankalar-60-ayrikalemde-ucret-aliyor, accessed on October 3, 2017.

40 The minutes of the Parliamentary Commission are available in Turkish https://www.tbmm.gov.tr/develop/owa/komisyon_tutanaklari.tutanaklar?pKomKod=36\&pDonem=24\&pYasama Yili=3, accessed on December 10, 2017.

${ }^{41}$ Interview, R5, BRSA, Ankara, January 11, 2016.

${ }^{42}$ Interview, M1, Ministry, Ankara, March 28, 2016.

${ }^{43}$ Interview, B3, T. Is Bank, Istanbul, February 24, 2016.

${ }^{44}$ Interview, B6, Finansbank, Istanbul, February 10, 2016.

${ }^{45}$ Interview, R3, BRSA, Ankara, January 21, 2016.

${ }^{46}$ See Coban (2019) on the BRSA's subordination of the banking sector during compliance with the Basel framework despite the latter's critical, sceptical approach on full compliance. 